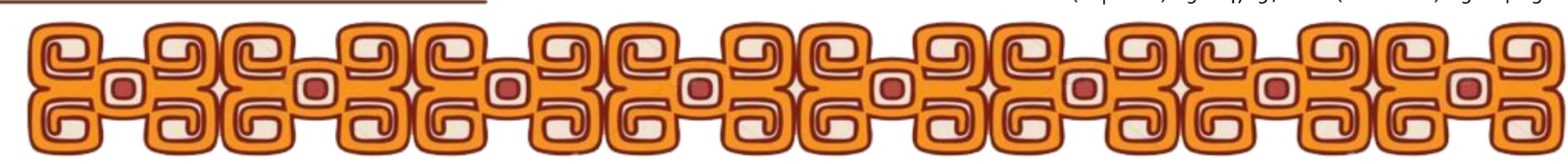

\title{
O NEOLIBERALISMO E SEUS DESDOBRAMENTOS
}

Michel Justamand

\section{RESUMO}

Muito já se falou ou mesmo escreveu sobre o Neoliberalismo, principalmente os intelectuais de esquerda. Eles mostram que este sistema político, econômico e cultural, ora imposto aos mais diferentes povos do mundo, é completamente inviável ou ainda excludente. Mas ainda é possível acrescentar críticas, interjeições e idéias no que já foi produzido. Os valores embutidos nas relações neoliberais que o perpassam são categoricamente destinados a iludir e excluir os outros, aqueles que sejam diferentes da ortodoxia anglo-saxão, liberal, protestante e, notadamente, empresarial, sem esquecer machista e da elite branca.

\section{PALAVRAS-CHAVES}

Neoliberalismo; Capitalismo; Economia.

\section{INTRODUÇÃO}

O neoliberalismo tem força hoje porque, segundo José Luís Fiori, houve um casamento virtuoso e vitorioso entre as suas principais idéias (visto que a partir dos anos 80 o neoliberalismo viveu colado com o capitalismo) e o movimento real do capitalismo. Ambos visando e buscando a desregulamentação crescente e a globalização econômica de natureza financeira (FIORI, 1998, p. 218).

Essas ações são perpetradas com imensas possibilidades e permitidas por governos submissos. Dessa forma os neoliberais agem praticamente sem controle, como diria Said, aprisionando o mundo com suas garras (SAID, 2003, p. 88). E gerando graves conseqüências tanto para a democracia real participativa, que deixa de existir nesse sistema econômico, quanto para o meio ambiente, que no imenso afã da produção o destroem sistematicamente (JUSTAMAND, 2010).

Os empresários, da maior força imperial militar que a terra já viu, levam toda a vantagem possível como maiores aproveitadores do sistema que difundem como sendo o melhor para todos. Além de terem seus próprios investimentos

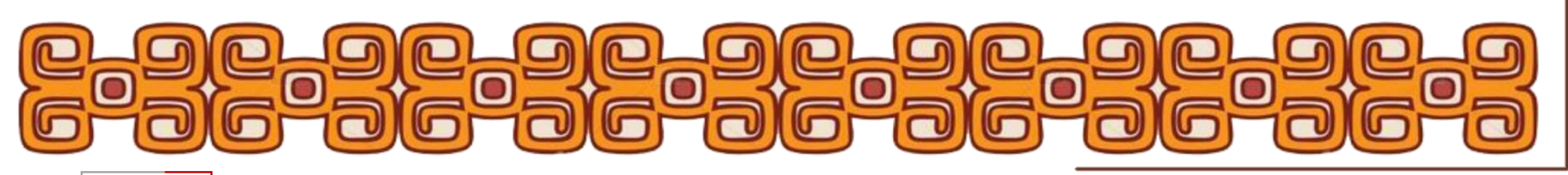




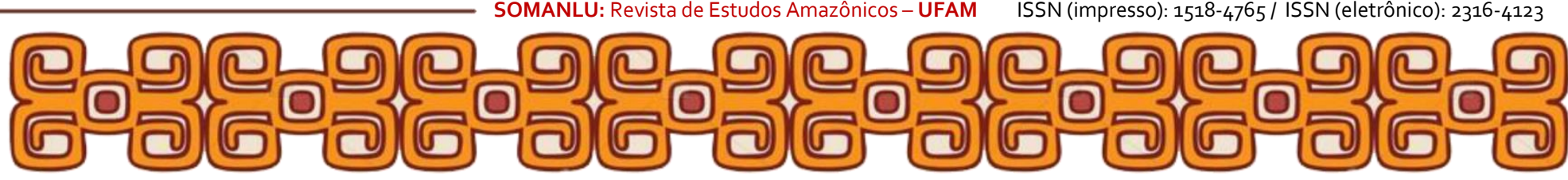

internacionais, que não são poucos, muitas empresas do país são financiadas pelo dinheiro árabe ou japonês ${ }^{1}$, e ainda têm garantido toda a ajuda que for preciso de seu próprio governo, os EUA.

Em todas as áreas de atuação comercial, industrial ou de serviços os mais variados empresários estão presentes ou têm seus interesses, ou seja, terão enormes lucros com as investidas de seu governo, construído e constituído logicamente por eles mesmos e para o seu benefício. Isso se dará em "guerras de prevenção" ${ }^{2}$, como costumam chamar, como a Invasão do Iraque, por exemplo, que lhes permitirá lucros acima do esperado e em tempo recorde.

As raízes de todo o processo hoje em andamento, dependendo dos pressupostos adotados pelos mais diversos teóricos, podem encontrar-se há muitos séculos atrás, mas adotaremos como ponto de partida para a indicação de suas raízes iniciais o final do século XV, quando houve as chamadas "Grandes Navegações". Um eufemismo para o que realmente ocorreu, ou seja, destruição, morte, genocídio, estupro, expulsão, tortura e exclusão dos habitantes das terras distantes da Europa. Assim como é o caso em grande medida da famosa e tão propalada "Globalização", que na verdade somente globaliza os valores e as verdades de uns poucos, que lucram enormemente com a extorsão sobre a maioria da população mundial.

Os neoliberais, por sua vez, querem impedir as transformações por meios sociais. Transformações que não são impostas de cima para baixo. Aquelas que podem gerar a reflexão e atuação contra o sistema do capital. Durante anos os pensadores conservadores em suas práticas e escritos tiveram essa iniciativa, ou seja, encobrir as lutas sociais por transformações, afirma Bianchetti (2005, p. 77).

A partir deste marco histórico e geográfico conhecido em todo o mundo, sem nenhum prazer, é lógico, depois de tantas mortes serem perpetuadas, é que levantamos nossos intentos contra o sistema até aqui auto declarado suficiente e belo para todos, mas que muitos tentam escondê-lo, o Neoliberalismo. Uma das muitas definições compatíveis com a causa desse livro é a dada por Chomsky: que ele é um

\footnotetext{
${ }^{1}$ Vide o filme 11 de setembro de Michael Moore.

${ }^{2}$ Nome dado às investidas estadunidenses em todo o mundo, quando acreditam ou têm a certeza de que não terão problemas militares para tomar de assalto um país indefeso como era o Iraque, para depois ocuparem com suas empresas ou indústrias.
}

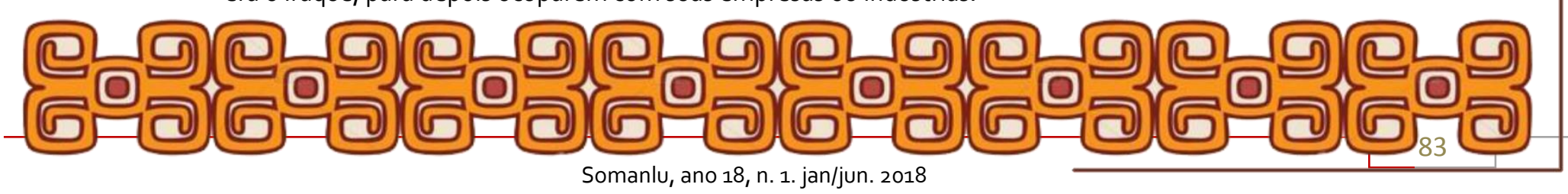




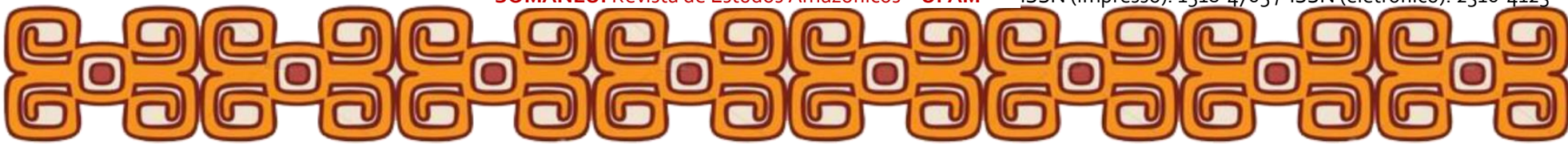

paradigma político definidor da economia dos nossos tempos. Com procedimentos que permitem para apenas uns poucos e seus interesses privados se sobreporem aos interesses da maioria da população mundial. (CHOMSKY, 2000, p. 07).

Neoliberalismo é o sistema que serve como uma fachada ao capitalismo voraz das grandes empresas. Sistema que no discurso deseja a aprovação da maioria e a crença de ser esse o modo de vida certo. Sendo assim esse molde é a melhor saída e trará a solução para a vida de todos, mesmo que seja muito lentamente e a longuíssimo prazo, como defendem seus teóricos. Ou seja, não temos chance como maioria de uma vida digna dentro de um modelo socioeconômico e político apresentado como mundial como esse (JUSTAMAND, 2010).

Não queremos melhorias lentas queremos a revolução política, social, cultural e mental. Queremos viver com mais dignidade agora. Sabemos que outro mundo é possível já; já basta desse que vivemos! Que mais explora do que colabora com a maioria!

Enquanto isso todos ficamos à espera da salvação divina e/ou empresarial para as variadas necessidades cotidianas. Como por exemplo: ter o que comer daqui a alguns instantes, ir à escola ou a um médico no posto de saúde mais próximo, que por causa do sistema não se encontram as soluções tão facilmente "ali na esquina".

Em nome de outra forma de pensar, ver e agir na sociedade-mundo é que se seguem as próximas reflexões, contestações, indicações, conjecturas, propostas e idéias. Dividem-se as argumentações sobre o tema em: um rápido histórico da globalização, a princípio; em seguida, o neoliberalismo e suas raízes; depois o processo de constituição do sistema neoliberal; apresentam-se suas conseqüências; em especial as questões voltadas para a educação; e, por fim, se é possível outro mundo a partir do entendimento de que existem outras relações humanas acontecendo na terra.

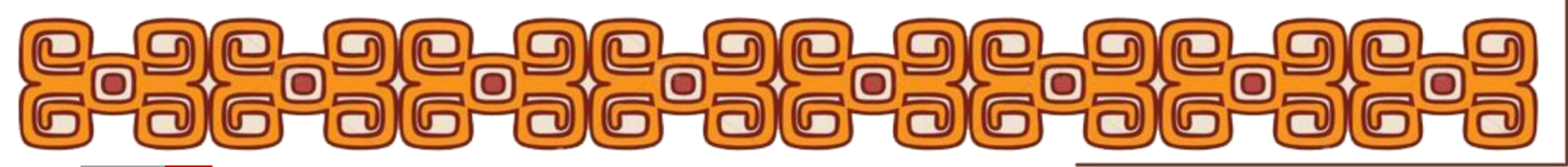




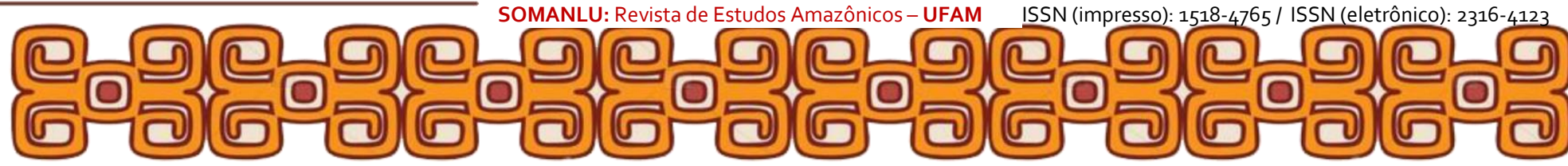

2 BREVE HISTÓRICO DA "GLOBALIZAÇÃO"

Una mano más una mano no son manos son manos unidas. Une tu mano a nuestras manos para que el mundo no esté en pocas manos sino en todas las manos.

Gonzalo Arango

O termo Globalização, para Chomsky significa o resultado da ação de governos poderosos, EUA principalmente, que forçam os outros povos do mundo a engolir os acordos que são bons apenas para os mais ricos. Facilitando assim a dominação econômica das grandes corporações sobre os mais indefesos (COHMSKY, 2000, p. 13). Já para Hobsbawm a Globalização seria um avanço acelerado de atividades interconectadas que as fronteiras dos países não a impedem e que provocou um impacto político e cultural enorme em muitas sociedades, mas que, sobretudo é um mercado global livre e sem controles (HOBSBAWM, 2007, p. 10). Assim, a Globalização assume várias roupagens, dependendo do local onde é escrito, ou pronunciado, ou ainda por quem ele é dito. Entre essas roupagens está a de que a Globalização seria um processo que beneficia a todos pelo mundo. Algo que discordamos, pois para nós o que realmente é globalizado é a exclusão social, econômica e cultural. Isso ocorre em alguns casos por meio das imposições comerciais e industriais aliadas às medidas bélicas de alguns Estados que se vêem como os donos do mundo. As empresas transnacionais são as principais beneficiadas com o processo. E elas vivem fora do alcance das leis e dos impostos do Estado (IDEM, p. 41).

No final do século XV, "empresários" europeus pleiteavam junto a seus governantes como angariar formas alternativas de obter mais lucros. O mercantilismo metálico foi a saída encontrada. Desta forma, foi-lhes garantido esse efeito de acumulação. A prata, o ouro e as outras pedras preciosas retiradas a fórceps das Américas e/ou da África permitiram tamanha acumulação que gerou abastecimento e fôlego novo ao comércio europeu, que se via combalido na época.

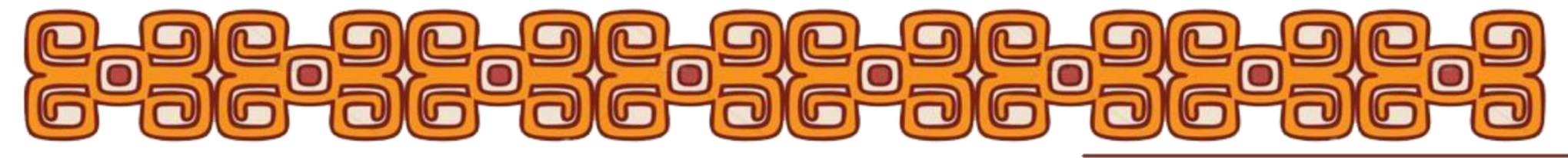




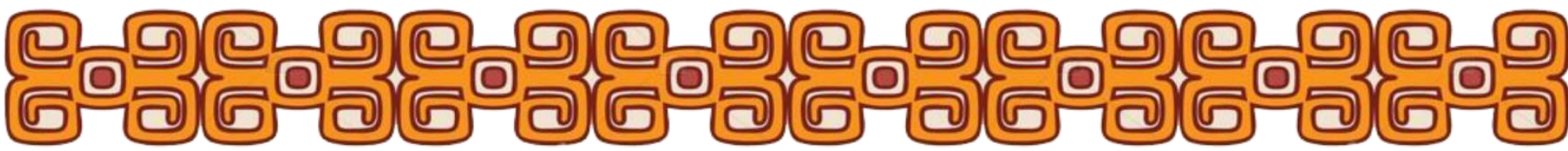

Comprar menos e vender mais esta era a lógica do mecanismo mercantil. Para isso, buscando-se sempre novos mercados. Isso era parte do esquema encontrar novos consumidores. E no período toda atividade comercial era controlada pelo Estado. Mas houve sempre quem não gostasse muito do controle do Estado, reis e rainhas. Mas esses descontentes comerciantes ou mesmo empresários estavam sem forças de reivindicação e então não conseguiram o que queriam nesse período.

Outros teóricos da época como os fisiocratas acreditavam na acumulação das produções agrícolas. Tais produções seriam as fontes para aumentar as riquezas das nações, segundo esses teóricos. Eles foram logo superados pela poderosa força dos mercados comerciais e suas divisas espalhadas naquele momento pelo mundo.

Neste contexto, os teóricos que defendiam as idéias daqueles que não acreditavam no controle do Estado acudiam-se então ao Liberalismo. Uma teoria que é a reação ao mercantilismo comercial, anterior, no início do que se convencionou chamar de sistema capitalista em meados do século XV e XVI. Conhecida por ser a que incentivava a exploração dos bens pilhados, ou melhor, usurpados, da África, da Ásia e das Américas.

Criticavam o intervencionismo do Estado na economia como era no caso feito pelo mercantilismo comercial. Inventaram as frases do liberalismo. Deixa fazer, deixa passar. Laissez faire, laissez passer (deixa fazer, deixa passar).

Tal teoria passou a ser dominante nos meios comerciais e depois industriais, entre os donos dos meios de produção, claro, aqueles que somente têm a ganhar, pois com o Liberalismo tinham muito a lucrar. O que diferentemente dos que não detinham os meios de produção, ou seja, a maioria da população mundial, foi fatalmente explorada, escravizada e excluída da participação nas tomadas de decisão que os afetavam diretamente.

As massas, ou as «bestas feras», como se convencionou chamar nos meios milhionários dos EUA, que são os mais pobres, se movimentaram, é claro, formaram seus agrupamentos, depois associações e mais tarde sindicatos. Tais aglomerações populares são algo que leva muito medo aos donos do poder.

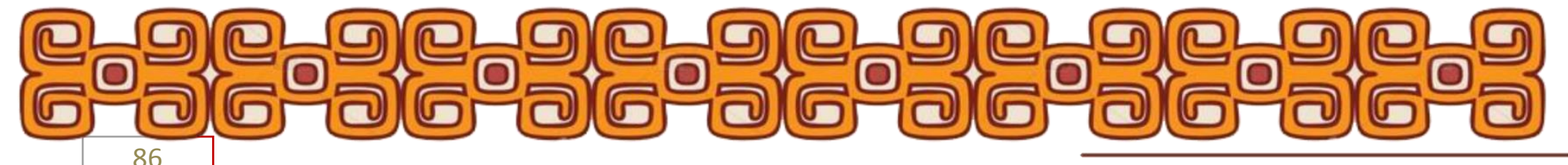




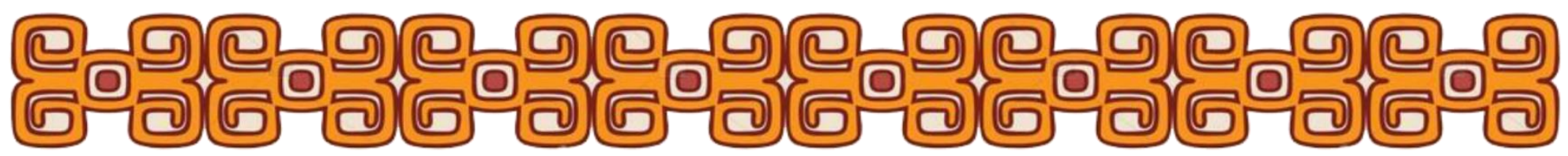

Fatos que ocorrem no intervalo entre os séculos XVII e XIX. Mas nesse mesmo período já havia indícios de grandes negociações internacionais entre as futuras potências européias sobre um conjunto de regras comerciais (BARBOSA, 2001, p. 24) sinalizando o que chamamos hoje de globalização.

Os patrões têm medo dos sindicatos ou seus similares, pois isso pode prejudicar o bom andamento dos negócios. Eles acreditam que perdem seus lucros com a exploração da mão-de-obra dos trabalhadores e/ou escravos do período caso existam tais organismos populares.

Criam diferentes teorias que são postas em prática para sabotar as movimentações dos assalariados ou escravos. Como por exemplo: o racismo, que na Europa pode ser entre grupos da mesma etnia, e/ou o nacionalismo. Ou ainda a crise internacional que é mais do que nunca sazonal e bem-vinda pelos empresários.

O primeiro que é o racismo, ou preconceito étnico, para que os descontentes, mas com as mesmas feições, cultura e cor tenham a quem culpar pelo seu destino e não os patrões, é claro. Desta forma, eles, os patrões, continuam a explorá-los e lucrarem muito com o próprio racismo.

E o nacionalismo era importante e justificável, pois a luta ou a guerra que eles incentivavam, mas obviamente não lutam e nem mandam seus filhos, contra o estrangeiro capitalista levaria os donos do sistema local a terem abertas novas divisas de lucratividade. Algo que é imperceptível aos olhos da maioria da população no momento da propaganda de guerra.

No início do século XX temos a maior arregimentação de humanos para a I Guerra Mundial, em que os donos do sistema vibram muito com a possibilidade de criação de novos espaços de lucratividade, assim como fora muitos séculos atrás no período inicial do mercantilismo. A guerra desse período é um exemplo claro de nacionalismo exacerbado e de abertura de novos espaços para a venda de seus produtos industrializados.

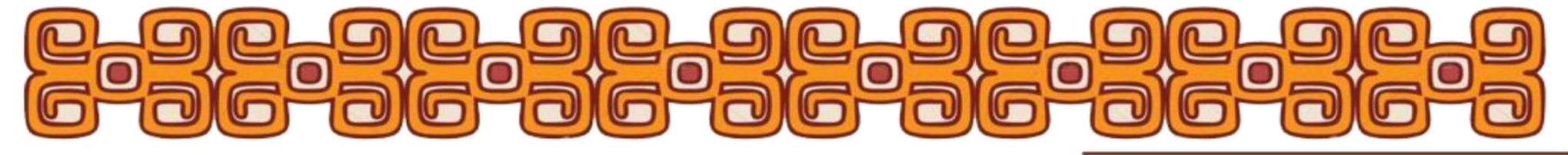




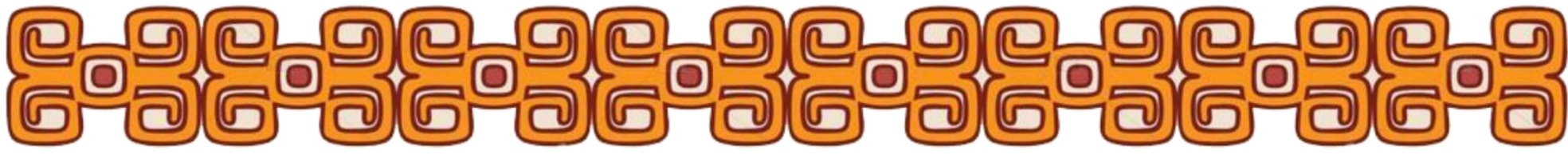

O período entre guerras que vem logo a seguir promove a ascenção de um regime político ainda mais repressivo e benéfico para as intenções dos teóricos do neoliberalismo, além da rescessão provida pela crise das bolsas de valores de $1929^{3}$, que fez a perifeira do mundo capitalista quebrar, pois ela dependia de suas exportações para os países centrais que não tiveram a partir de então como manter suas importações e ainda retiraram seus investimentos e capitais da periferia (BARBOSA, 2001, p. 30). Regime que se espalha por toda a Europa e depois para outros recantos do mundo, mas que ainda hoje, infelizmente, se tem exemplos disfarçados, mas bastante reais como é a ditadura de Bush (MOORE, 2004).

A II Guerra é um sinal de que o capitalismo precisava de novo fôlego para sobreviver, então, o que fazer destrói-se muito para depois reconstruir, ou seja, os EUA, principalmente e suas grandes empresas, incentivam a guerra, para depois com tremenda «benevolência» ajudar a reconstruir tudo com empréstimos financeiros, que serão pagos com altos juros.

Redundando naquilo que ficou usualmentte conhecido como o Tratado ou a Conferência de Brentton Woods (CHOMSKY, 2002, p. 164), onde foram criados o Banco Mundial e o Fundo Monetário Internacional. Ambos com sede nos EUA que por meio destes organismos internacionais ditavam as regras do mundo pós-II Guerra (01/07/1944), originalmente baseou-se no controle do capital circulante e mantendo as moedas relativamente fixas, beneficiando economicamente os governos e os ajudou a conduzir políticas sociais democráticas altamente populares (CHOMSKY, 2004, p. 142). Algo com o qual os neoliberais nunca concordaram. Os últimos 500 anos, infelizmente, foram marcados por uma série de idéias legitimadoras da manutenção do poder aos que o têm (WALLERSTEIN, 2007, p. 109).

Acordo que foi desmantelado por Richard Nixon em 15/08/1971, presidente dos EUA, quando decretou o fim da coversibilidade do dólar em ouro, que também significava o fim da relação com outras moedas do mundo (GONÇALVES e POMAR, 2001, p. 13). Sabendo que seu país era nesse momento detentor do poder de

\footnotetext{
${ }^{3}$ Essa crise internacional fez surgir o Estado de Bem-Estar Social onde os Estados Nacionais garantiam a população mais pobre os bens mínimos e básicos como a escola, a saúde e a segurança. Valores muito criticados pelos neoliberais que são contrários a qualquer intervenção financeira dos governos em benefício social.
} 


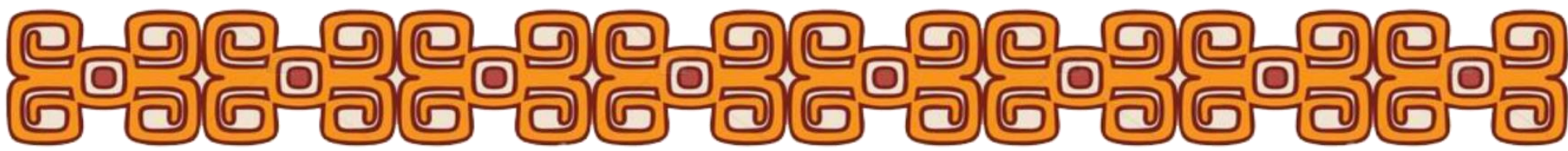

descreve o autor, privatiza empresas estatais que geravam lucros e, por exemplo, abrem os mercados para a penetração de empresas estrangeiras com inúmeros privilégios, como a redução de encargos sociais (IANNI, 1999, p. 217).

\section{NEOLIBERALISMO: AS RAÍZES DO SISTEMA ECONÔMICO}

A mais bela de todas as certezas é quando os fracos e desencorajados levantam suas cabeças e deixam de crer na força de seus opressores.

Brecht

O Consenso (neoliberal [CHOMSKY, 2002, p. 21]) de Washington seria um conjunto de medidas voltadas a atender as exigências do mercado financeiro e suas maiores empresas privadas, principalmente as dos EUA. Esse Consenso sem consentimento popular foi forjado pelos senhores da economia privada, ou seja, empresas gigantescas que controlam a economia internacional ou a maior parte dela e seus ideólogos (BARBER, 2005, p. 193). E o criaram para controlar ainda mais e ditar (CHOMSKY, 2002, p. 22) as regras para todo o sistema global de ações comerciais e financeiras. Ou seja, os mega-empresários desejam dominar e serem donos de tudo e de forma monopolista. Portanto, defendidos pelos teóricos neoliberais, fazemos um preambulo para lembrar dos dois mais conhecidos e influentes economistas Milton Friedman (In: Capitalismo e Liberdade) e Friedrich a. Hayek (In: O caminho da servidão). Segundo nossa ótica são os responsáveis pela desestruturação da base social, econômica, política e cultural, mundial, que era de um estado de bem-estar garantido para certa camada da população e que se perdeu completamente que era anterior as suas propostas neoliberais. Voltando, depois dessa digressão, os empresários desejam que o mercado funcione como uma ordem espontânea (ROMÃO, 2000, p. 168), que é instintiva somente para eles e seus benefícios, mas que obviamente é uma mentira e que somente favorece uns poucos.

Márcio Pochmann afirma que no atual sistema os pobres é quem mais pagam impostos proporcionalmente, pois o sistema tem operado de forma regressiva,

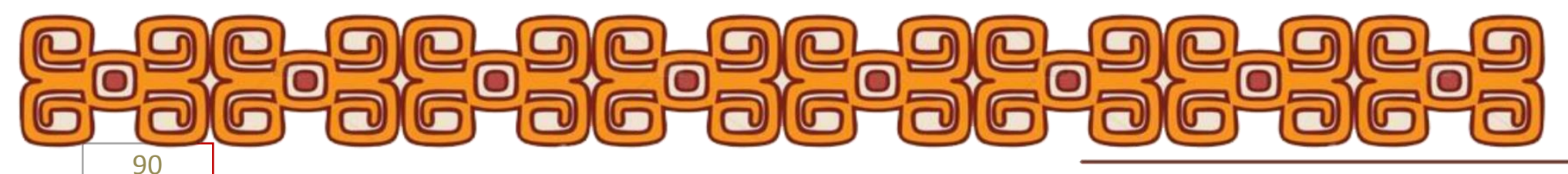




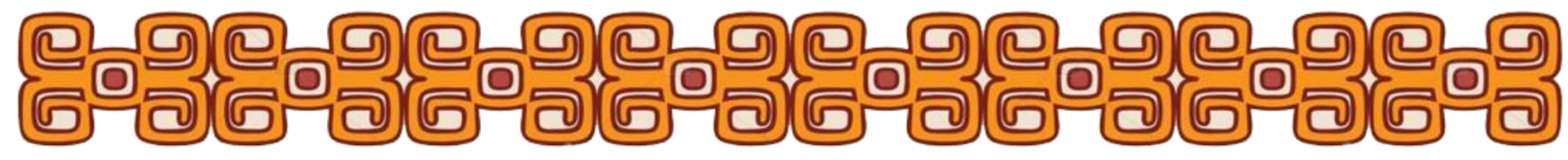

garantindo assim que os mais ricos passem quase que incólumes pelos pagamentos de impostos (POCHMANN, 2007, p. 18).

Assim os meios de comunicação dos países poderiam passar às mãos de empresários estrangeiros dificultando, obviamente, a democracia real naquele determinado país. As concentrações financeiras também nas mãos de gringos impedem o envolvimento e o planejamento popular nas questões que lhes dizem respeito. O pior talvez seja o controle da produção da alimentação se for feito por parte de empresas de outros países, essas que evidentemente têm seus interesses voltados a retirar o máximo lucro e enviar para fora, ou mesmo as nacionais que imbuídas de um interesse unicamente econômico, dificultam a sobrevivência local (CHOMSKY, 2000, p. 76).

No processo econômico neoliberal os trabalhadores, o lado mais fraco, quem mais sofre com o sistema, eles são aquartelados e mantidos em "presídios", nas instituições onde desenvolvem suas lidas. Local no qual executam jornadas de trabalho longas e quase não há precauções com a segurança, fato que ocorre atualmente na China, mas é de se acreditar que ocorra também em muitos outros países que aceitam o ideário do sistema (KURZ, 1997, p. 228).

Para os neoliberais é importante passar as mãos das tiranias privadas (CHOMSKY, 2004, p. 12-3), as megaempresas privadas, o controle às decisões fundamentais da sociedade. Elas não prestam contas de suas ações. Dessa forma, os neoliberais conseguem, conforme é de seu interesse, diminuir ou restringir a esfera pública. Eliminando quase que totalmente a democracia, pois a população cada vez mais estará afastada das decisões realmente relacionadas com suas vidas e aos seus intentos reais e mais diretos como as questões concernentes à educação, saúde, moradia, segurança e trabalho.

\section{ENTENDENDO O PROCESSO NEOLIBERAL}

Com esses contratos feitos entre o governo e as empreiteiras, o Brasil inova mais uma vez: não temos só assaltantes de estradas, temos estradas de assaltantes.

Millôr

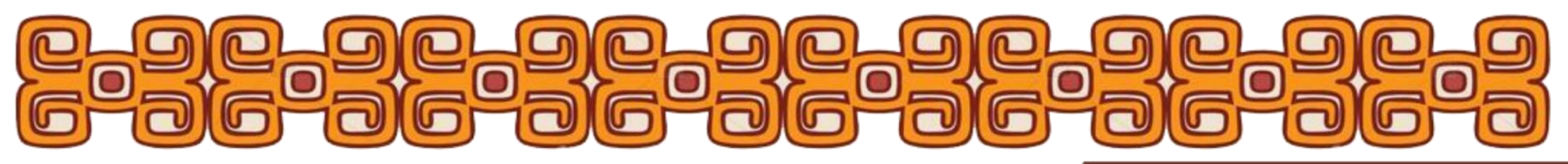




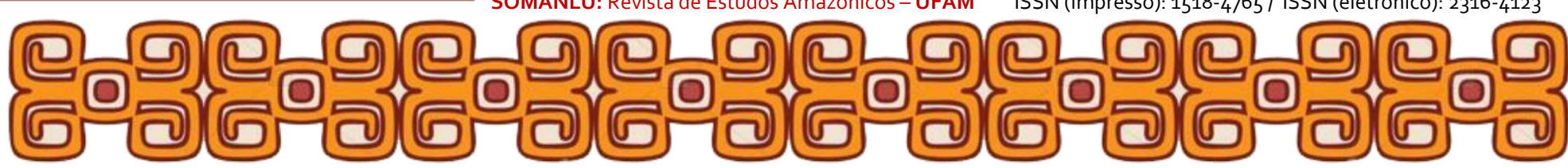

A ofensiva dos EUA em enfrentamentos na região do Oriente Médio, nome criado pelos "ocidentais" para se referirem àquela parte do globo (SAID, 1990)' tem a ver, sem dúvidas, com o abastecimento das fontes energéticas, mas principalmente para a Europa e Japão, regiões que dependem dessas fontes energéticas.

Para os EUA é vital impedir que o Japão e a Europa, em especial a Nova Europa, ou seja, a Alemanha e a França tenham acesso a essas fontes, conforme análise de Chomsky. Os esforços dos yankees é que os novos europeus tenham grandes dificuldades para penetrar no mercado externo. Dessa forma, eles os yankees têm seus ideais, produtos e empresas prosperando mundo afora.

Os EUA não dependem das fontes energéticas do Oriente Médio como se pensa. Têm sua própria produção e conseguem petróleo por outras fontes no mundo, como da América Latina, por exemplo.

No caso da América Latina os EUA exercem pressões desde o pós-II Guerra. A mais atual chama-se Plano Colômbia que é um plano de intervenção militar na região e que pretende usar todo o espaço aéreo colombiano para tomar de assalto o norte da América do Sul. Incluindo aí a Venezuela, rica em fontes energéticas como é o petróleo.

Há anos os EUA treinam e doutrinam militares da América do Sul e Central guiados para seus interesses manipuladores e escusos ${ }^{4}$. Preferencialmente para impor seus desejos imperialistas e hoje chamados "globalizadores". Usam-se da força caso seja necessário, como já se fez anos anteriores com inúmeros países, como a Guatemala, Nicarágua (JUSTAMAND, 2014-2015), El Salvador, Granada, Haiti, Honduras, Brasil, Chile (CHOMSKY, 2013).

A política econômica neoliberal é uma capa protetora das ações dos EUA pelo mundo. Não mostrando para todos, principalmente os mais ingênuos, a verdadeira faceta do mal que ela esconde, ou seja, desemprego, subemprego. Mas também o controle das ações dos estados nacionais, imposições monetárias, cortes orçamentários com os gastos públicos, desvios dos investimentos públicos para os

${ }^{4} \mathrm{O}$ filme Escola das Américas retrata bem esse cotidiano de "trabalhos" militares sem fins de destruição.

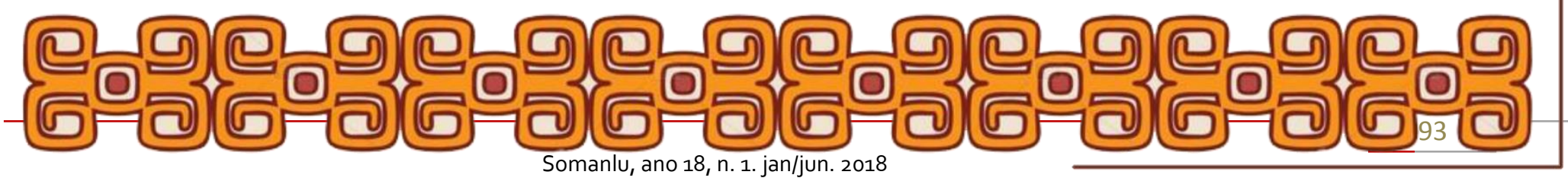




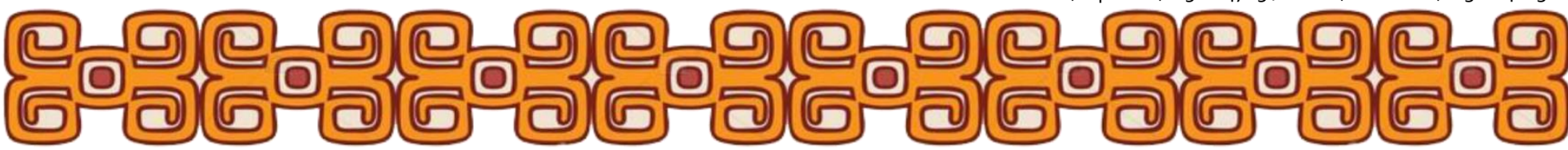

setores privados e a concentração infinita da renda nas mãos de poucas pessoas (JUSTAMAND, 2010).

Com essa política incentivam-se a quebra de países como a Argentina, o México e a queda das bolsas asiáticas. Conseqüências das propostas neoliberais que foram aceitas pelos "sócios menores" do grande capital, ou seja, as empresas dos países "satélites", que aceitam receber uma pequena parte do "bolo" dos investimentos. E desta forma são coniventes com a destruição dos direitos sociais adquiridos à custa de muita luta pelos trabalhadores. Isso para os que conseguiram, pois, essa luta resultou no estado de bem-estar social que previa algumas melhorias aos mais excluídos. Tal situação não adveio em todos os países.

Nos últimos 35 anos incidiu com maior profundidade a crise segundo os neoliberais, ou seja, como acreditam, é preciso apertar ainda mais o cinto e cortar, então, mais os direitos da maioria e transferi-los para a camada, ou classe social, mais privilegiada. Com os "apertos dos cintos" indicados pelos neoliberais quem mais sofre são os mais pobres (CHOMSKY, 2004, p. 211).

Há uma profunda relação entre a economia de mercado, tão realçada e dignificada atualmente, e as estratégias políticas imperialistas globais disfarçadas de neoliberais ou ainda de globalização.

O grande capital financeiro não consegue solucionar a crise mundial préexistente. Uma crise do desemprego em massa e da conseqüente queda dos níveis de vida da maioria. Um dos principais aspectos da crise para os mais pobres é a queda no poder de compra de seus salários, ou de seus ganhos com seus subempregos. Subempregos são aqueles sem registro e sem pagamentos de impostos, pois cada vez que sobem os preços articulados pelos neoliberais e os salários ou ganhos dos pobres não os acompanham eles perdem seu poder de compra (PEDEX, 1993, p. 57).

Gerando a pobreza absoluta em todos os recantos do planeta. Onde a média dos mais pobres vive com o equivalente a um dólar por dia para manter todas as suas necessidades vitais, como: comer, beber, vestir, educar-se, morar, ter saúde e segurança em seu próprio lar.

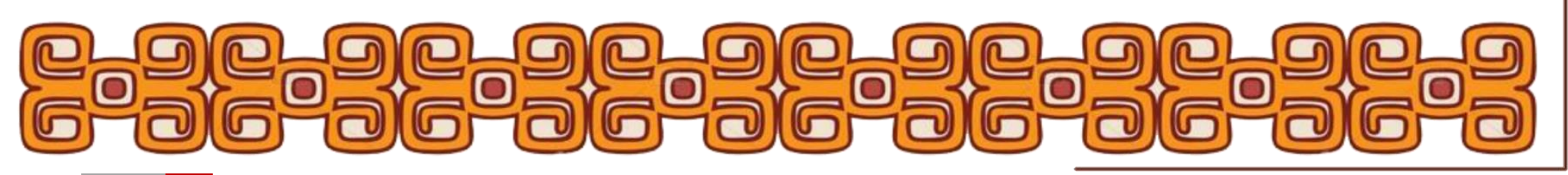




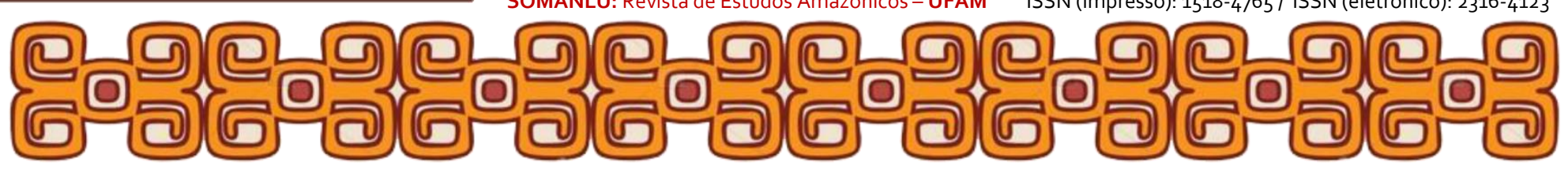

Um crescente deslocamento dos camponeses de seus espaços para o meio urbano também é uma conseqüência das medidas neoliberais. Junto deste deslocamento ocorre o aumento dos níveis de desemprego, pois todo um grupo que

antes não dependia dos aspectos sociais dos meios urbanos passa a ter necessidade de usufruir, assim favorece o desemprego estrutural.

O desemprego estrutural gera por sua vez alguns aspectos neoliberais declaradamente, como: a concentração de riquezas proporcionando para algumas empresas o próprio monopólio; as fusões de grandes corporações com sua conseqüente concentração bancária e comercial; a privatização da economia local via grande pressão internacional daqueles Estados e nações que assim fazem participam da tal globalização; o protecionismo econômico com a formação de blocos econômicos como o NAFTA ${ }^{5}$, MERCOSUL ${ }^{6}$, União Européia ${ }^{7}$; esses blocos econômicos acabarão por se chocarem graças às pressões de suas grandes empresas em busca do monopólio da divisão do bolo da grana internacional.

De todo o montante econômico disponível hoje no mundo $70 \%$ está nas mãos de sete países, enquanto que os outros $30 \%$ estão divididos entre todos os outros 200 países do mundo.

No mundo pós-II Guerra e suas conseqüentes divisões territoriais por blocos econômicos e seus interesses de explorar espaços onde ainda não exploravam apareceu. Após a grande guerra mundial os EUA passam a apoiar os líderes fascistas de alguns países. Algumas vezes "pedem" para que se deem aspectos mais humanos (CHOMSKY et al, 1979, p. 203) para suas ações. Pensamos que para obviamente não parecer uma recuperação do nazismo, mas que sem dúvidas, para nós, o neoliberalismo o é (JUSTAMAND, 2010).

Entre os países que lideram ataques de diversas formas: bélicos, diplomáticos, econômicos, ou burocráticos, estão os EUA, a Inglaterra e Israel, além de parte da Comunidade Européia. Buscam controlar as fontes energéticas do mundo e também a matéria-prima que estiver à disposição nos locais onde têm o domínio político,

\footnotetext{
${ }^{5}$ Tratado de Livre Comércio entre os países da América do Norte.

${ }^{6}$ Tratado de Livre Comércio entre alguns países da América do Sul.

${ }^{7}$ Tratado de Livre Comércio entre alguns países da Europa.
}

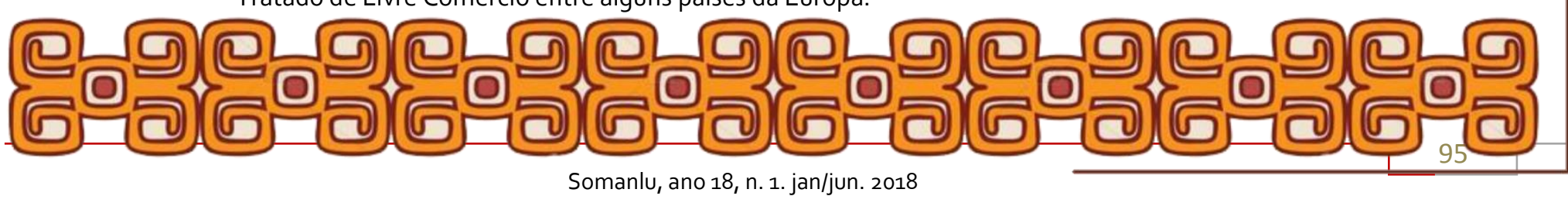




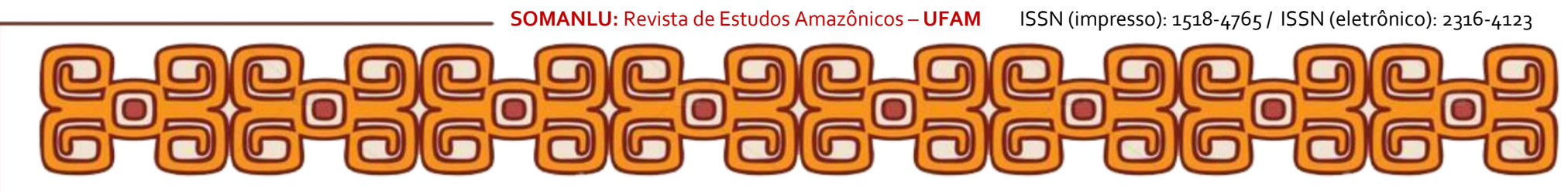

quem compra o que e de quem.

Evidentemente que os moradores e os próprios administradores locais passam a aceitar as imposições do sistema e consumir os produtos vindos do estrangeiro, ou seja, dos estadunidenses. Então aquela velha máxima que diz que você deve fazer o que digo e não o faço entra muito bem aqui, pois o protecionismo somente serve às intenções dos países dominadores; na terra dos outros eles não são a favor do protecionismo interno.

Com este tipo de situação instalada pelo mundo a indústria armamentista ganha um fôlego novo no pós II Guerra Mundial aumentando seu poder em todos os recantos do mundo, impondo os valores a serem seguidos, ou seja, calem-se quando eu estiver falando e quem pode mais chora menos. Sendo que a indústria armamentista estadunidense é a que tem crescido mais nos últimos anos, inclusive com investimentos do próprio governo, ou seja, a população, sem saber, dos EUA financia a morte de muitas pessoas e a destruição de inúmeros países ao redor do mundo.

O governo dos EUA tem investido uma somatória de dólares na indústria das armas por ano equivalente a duas dívidas externas do Brasil. Enquanto que a Europa tem investido 60 bilhões de dólares, bem menos que os estadunidenses, mas isso não quer dizer que também os europeus não deveriam deixar de se armar e investir em melhorias para os mais necessitados.

O desenvolvimento de tendências bélicas é ainda um resquício das políticas da época da famosa Guerra Fria, que servia para os governos tanto dos EUA quanto da URSS controlarem suas respectivas populações dentro de seus sistemas imperiais de mando. A guerra que muitos pensaram ter acabado com a queda do muro de Berlim, mas que continua quente e entre os países que desejam a hegemonia mundial. Gerando no Pós-Guerra Fria o aumento da concentração de riqueza nas mãos de uns poucos empresários (CHOMSKY, 2007, p. 45-47). Esse desenvolvimento bélico leva a um conseqüente choque entre os grandes capitais das maiores empresas do mundo. Elas impõem então as estratégias e as políticas a serem perpetradas por seus governos, que funcionam como marionetes do sistema.

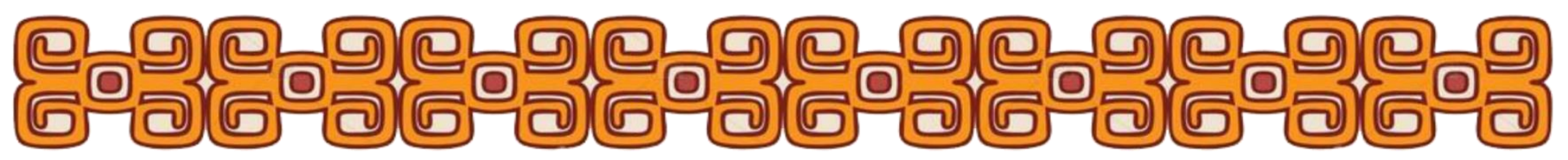




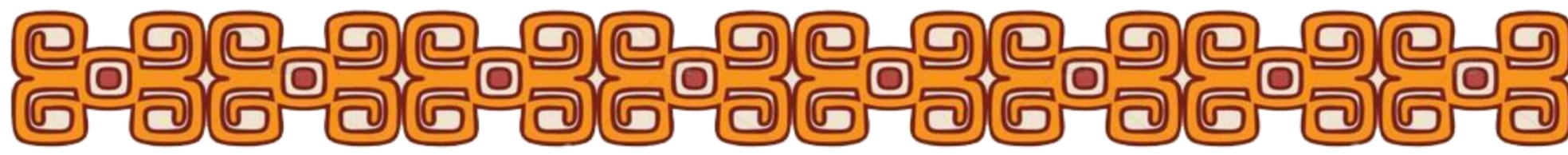

nascentes recuarem; na Argentina o recuo em suas produções industriais chegou a $20 \%$, frente ao grande poder de persuasão dos produtos vindos de fora de suas fronteiras imporem aos consumidores locais o que devem comprar, como e quando.

No caso do Brasil, podem-se repetir os resultados da Argentina, ou seja, perdermos a concorrência produtiva com os produtos vindos de fora $\mathrm{e}$ conseqüentemente muitas indústrias e pequenas empresas fechariam suas portas.

Temos aceitado passivamente a propaganda de que a privatização, ou seja, o modelo neoliberal de viver é uma possibilidade de um futuro melhor, para todos, inclusive. Mas como todos podem notar são privatizadas as empresas estatais que de alguma forma rendem mais e já estariam prontas, assim, quem as compra não têm prejuízo de início, recebe o financiamento, às vezes, do nosso próprio governo. E ainda essas empresas têm muitos anos para pagar e a juros baixíssimos.

As privatizações são as reduções da esfera pública e suas decisões para as mãos das tiranias privadas que não prestam contas do que acontece para ninguém. Essas tiranias que tomam conta atualmente das empresas que eram públicas e que realmente davam lucros para os seus governos (CHOMSKY, 2004, p. 24).

No caso do Brasil, as empresas estatais foram preparadas para a privatização com o dinheiro de todos, pois o governo investiu em muitas delas antes de vender. Ou ainda engoliu dívidas bilionárias, demitiram funcionários e aumentaram suas tarifas beneficiando os futuros compradores que teriam menos com o que gastar em suas "novas empresas" (BIONDI, 1999, p. 05).

Isso é um saque para cima dos países pobres pelos ricos. Para eles mesmos não quebrarem. Empurrando a crise para os outros. Prática comum entre os teóricos e os países decididamente neoliberais. Deixe sempre o problema para os "próximos da fila".

As nações mais atrasadas se tornam ainda mais atrasadas, pois não há ajuda para o seu desenvolvimento e sim mais controle e imposição do que se deve fazer via FMI e Banco Mundial, organismos internacionais controlados pelos representantes dos países ricos.

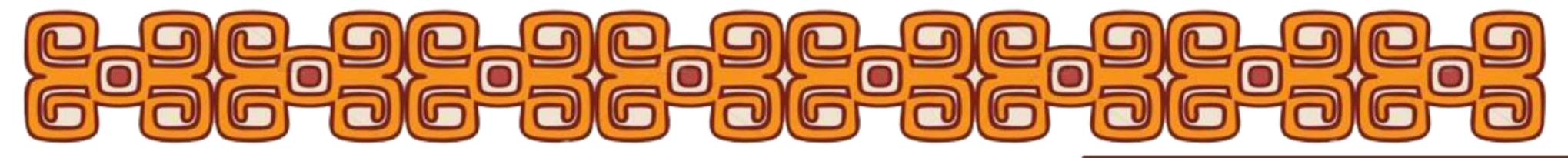




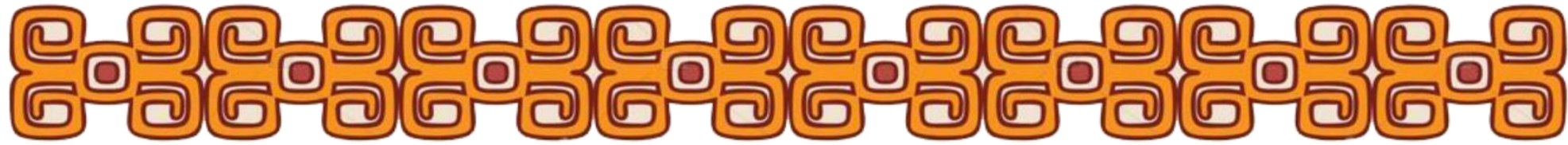

Infelizmente quem paga toda a conta dos despachos neoliberais pelo mundo no final são assalariados, em especial, aqueles que têm menos poder aquisitivo, com seus parcos recursos recebidos de forma suada ao cabo de muitos dias de trabalhos prestados aos donos do poder monopolista.

Os camponeses e os trabalhadores assalariados são os que mais perdem com as investidas neoliberais que concentram poder e riqueza nas mãos de poucos. Ou seja, a maioria da população mundial.

Assim milhões ficam sem poder consumir o elementar para suas próprias vidas; tornam-se meros receptáculos dos desígnios do sistema. Não têm vontade própria ou aceitam simplesmente aquilo que lhes cabe, quase nada da famosa fatia do "bolo" que há muito tempo falam os donos do poder que será dividida entre todos.

O neoliberalismo também é capaz de garantir o emprego informal para a imensa maioria da população. Segundo o Programa Regional de Emprego para a América Latina e Caribe (PREALC), são características do emprego informal: pequenas atividades urbanas, geradoras de renda, sem registros em carteira, ou seja, sem nenhuma proteção assistencial; usa-se de técnicas rudimentares e mão-de-obra sem qualificação. Não acumulam capitais e assim não podem pedir financiamentos ou créditos (JAKOBSEN et al, 2001, p. 13-4). Desse modo, são mantidas milhares de pessoas em situação de miséria ao redor do mundo.

É preciso ainda esclarecer que para o sistema capitalista crescer é preciso crescer a miséria social e em larga escala. Caso contrário os lucros não alcançam os níveis desejados pela fatia mais rica da população mundial. Não pode ser para poucos a miséria somente com um número considerável de miseráveis é que o sistema se mantém operante e ativo. Deixando-nos claro que a miséria estrutural é interessante para a manutenção do status quo.

\section{AS CONSEQUENNCIAS}

Coragem é resistência ao medo domínio do medo e não ausência do medo.

Mark Twain

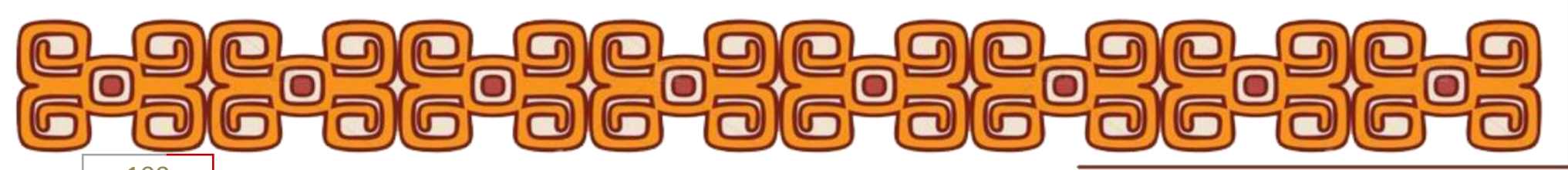




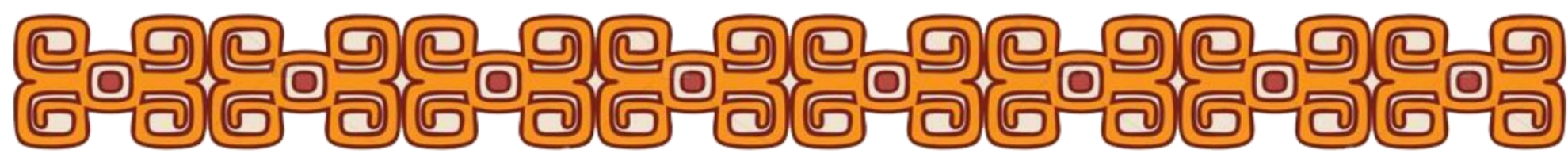

A alta classe média dominante tem em sua ideologia que pagar o ensino é normal e natural. Transmite-se essa mesma ideologia para os mais desfavorecidos economicamente e com a distribuição de algumas bolsas de estudos ilude-se a todos.

Se ganha muito com essa política neoliberal de transmissão dos financiamentos públicos para as instituições privadas de ensino. O governo em sua propaganda eleitoral na época das campanhas e na divulgação de que é um trabalho de responsabilidade social com a maioria dos desafortunados do sistema. Mas que na verdade a ação do governo apenas é de distribuir migalhas para que a maioria dos desafortunados pelo sistema não se rebelem e tentem mudar o status quo.

Uma das atitudes mais marcantes dos neoliberais diz respeito à precariedade dos postos de trabalho. Para isso são utilizados mecanismos sados-masoquistas, como pagar cada vez menos aos trabalhadores, explorar o trabalho feminino, deslocar as suas indústrias para locais onde não existam sindicatos, exatamente para impedir as mobilizações trabalhistas que para os capitalistas são prejudiciais, ou mesmo pagamento de impostos.

Os neoliberais têm "um sonho" e querem ver perpetrado, de preferência "pregado", nas cabeças de todos, é o de que o mundo é formado por indivíduos "racionais", que somente agem de acordo com uma razão mercadológica, e que estes indivíduos não querem mudar nada. Acreditamos aqui que não mudar é manter a sociedade desigual. As coisas todas devem continuar do jeito que estão, pois como estão é que é "bom", bom para os que estão com o controle do sistema. Não acreditamos nisso, temos a nítida impressão de que existe um desejo de mudança entre as pessoas. E mudar para que todos tenham uma vida mais digna.

Os neoliberais que se consideram seres "racionais", desejam mesmo é a paralisia mental, transformar todos em objeto de seus desejos, a massificação, a asfixia mental, ou ainda a manipulação. Aspectos da vida de todos que estariam para eles acima de qualquer outro motivo, seja humanitário ou social.

Por isso é importante que ainda existam algumas formas de resistência aos seus desígnios ditos naturais e impostos. Assim as lutas contra esse modelo econômico têm tido ecos pelas ruas, avenidas, escolas, bairros, cidades, estados e

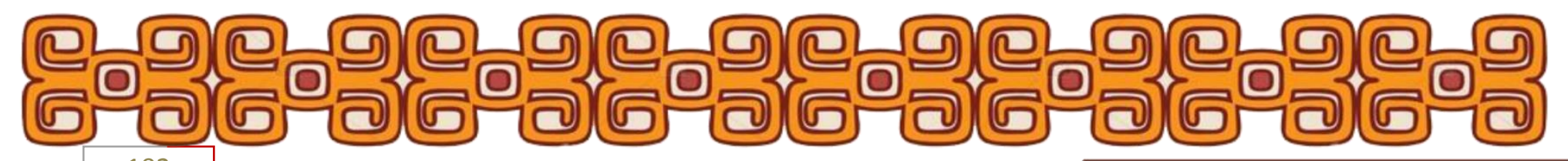




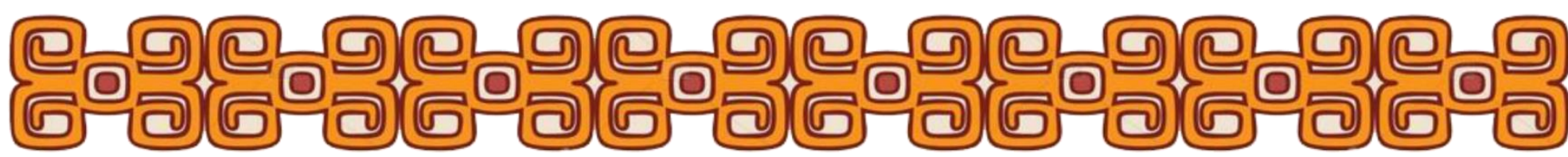

nações. Como mostram fotografias documentando as manifestações anticapitalistas, antiglobalização, anti-imperialismo, anti-neoliberalismo e anti-guerra contra o Iraque, realizadas em São Paulo a partir de 2001 (RYOKI e PRTELLADO, 2004).

Um dos maiores objetivos dos neoliberais é criminalizar todos os movimentos sociais para desta forma impedir que se aumente o número de associados nos quadros sindicais, que como afirma Said. Justamente os sindicatos que surgiram como espaços dinâmicos e organizados da sociedade, mas que para o sistema tinham que ser quebrados, e assim o foram (SAID, 2003, p. 89).

Os sindicatos e a reivindicação mundial pelos direitos humanos nos EUA são vistos como incentivos aos oprimidos e não são necessários verdadeiramente, ou seja, nos discursos aparecem, mas na prática política não. Para Chomsky, os investidores internacionais com grandes capitais querem manter contida toda e qualquer forma de revolução ou contrariedade ao sistema (CHOMSKY et al, 1979, p. 193).

O objetivo de destruir os sindicatos entre os neoliberais dos EUA, em especial, é que eles são ainda um dos únicos e poucos mecanismos pelos quais pessoas comuns podem se juntar e compensar a concentração de capital e poder (CHOMSKY, 2006, p. 181). Neles notam-se espaço onde os mais excluídos unidos podem fazer frente ao grande capital. Podem fazer frente também aos mandos e desmandos dos representantes do poder nas empresas. Mas infelizmente alguns desses representantes sindicais mudam-se até de lado quando recebem um cargo de poder.

Os movimentos reais de luta, como o MST - Movimento dos Trabalhadores Rurais Sem Terra, o MSTC - Movimento dos Sem Teto do Centro de São Paulo, o movimento Punk e o Hip-Hop, entre outros, também devem ser criminalizados como desejam os controladores do sistema e seus representantes. Por representarem problemas a manutenção do sistema como ele é.

Deseja-se a todo custo, então, glamourizar o crime, transformá-lo em algo a ser combatido, mas não tanto assim, pois afinal de contas isso também sustenta 0 sistema. Distancia as massas oprimidas da realidade que é o sucateamento das condições de vida precárias em que vivem. Na educação, na saúde, no emprego, na segurança social e na moradia, tudo é então escondido para não ser alvo de críticas.

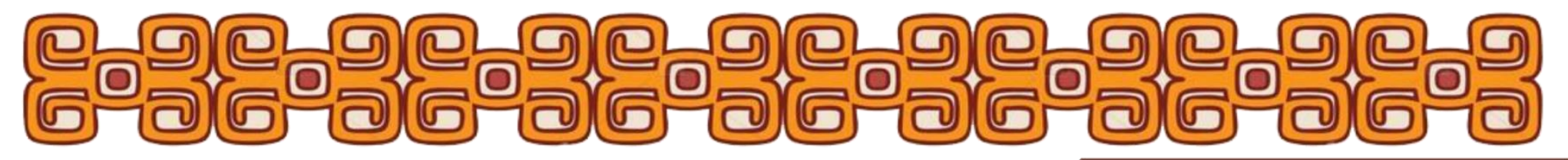




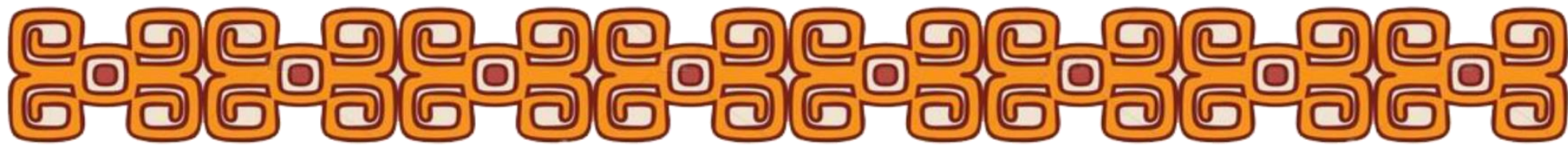

Enquanto que o banditismo é visto e explorado cotidianamente nos meios de comunicação. Mostrar isso freqüentemente é uma forma de esconder as mazelas e golpes da burguesia internacional na maioria da população mundial.

Os neoliberais não assumem claramente, mas um dos principais problemas do mundo é a existência da possibilidade de a democracia ser vencedora e desta forma perderem seus "direitos, privilégios e regalias". Assim, é preciso, para eles, derrubar todas as formas democráticas de vida. Entre elas o direito de todos usarem de forma igualitária os bens gerados pelos humanos desde os tempos ancestrais até hoje, como o conhecimento técnico científico tanto nas escolas quanto nos hospitais.

O atual governo brasileiro do PT - Partido dos Trabalhadores - tem sido conivente com todas as intenções do modelo econômico vigente. Tem imposto de maneira muito eficaz, sistemática e rápida as reformas que anteriormente foram dificultadas por seus próprios deputados e senadores. Entre essas reformas está a da previdência pública que foi reformulada dentro dos moldes neoliberais no governo LULA e que antes no do FHC não conseguia ser aprovada.

O PT ao longo de sua história de luta apresentava-se a todos como dentro da oposição. E assim antes, rechaçava as reformas do projeto neoliberal, como por exemplo, da previdência. Mas agora esta desiludindo os que antes acreditavam em suas intenções. Por encampar os desígnios neoliberais.

O governo Lula tem seguido fielmente o receituário imposto pelos organismos internacionais como o FMI, BM (Banco Mundial) ou ainda a OMC (Organização Mundial do Comércio). Aceitando manter fora das decisões a maioria da população. Realizando as reformas para garantir a alguns poucos humanos todo o lucro e a muitos o sofrimento.

Hoje existem muitos estudantes universitários brasileiros financiados pelas "bolsas" dos governos neoliberais. Mas entendemos que, por exemplo, não adianta terem um canudo universitário e não terem onde exercer suas funções aprendidas nos bancos escolares.

No princípio o neoliberalismo sempre pretendeu promover a hegemonia de suas grandes empresas e prometeu para a grande maioria da população mundial um

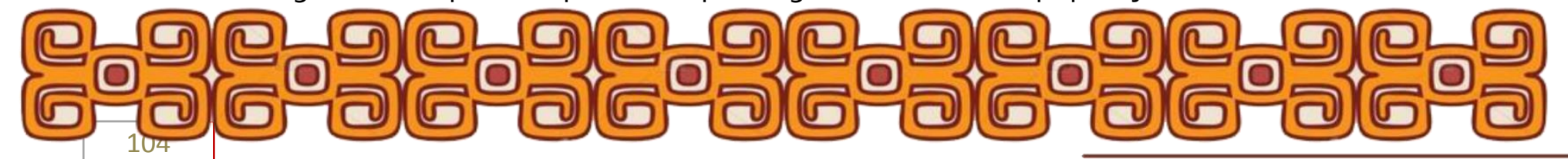




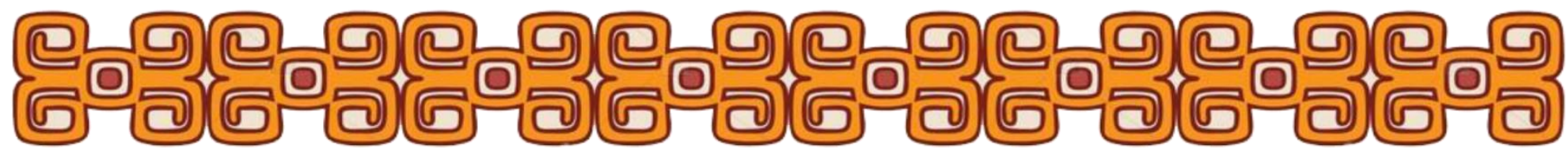

mundo melhor, foi um golpe sistemático; ao contrário do que se esperava o cinismo imperou e a corrupção aumentou. A exclusão e a precariedade imperam.

As informações sobre as reais necessidades de todos são escondidas, manipuladas e controladas pela grande mídia.

Para os neoliberais entre os muitos setores da vida social que têm relevância dentro de suas táticas de cortes de gastos públicos e lucratividade está a educação. A relação entre o programa neoliberal e a educação será tratada a seguir.

\section{A EDUCAÇÃO E O NEOLIBERALISMO}

O caminho do inferno já não está mais calçado de boas intenções. O diabo mandou refazer o calçamento com o patrocínio da Coca-cola.

Millôr

Para os neoliberais a educação tem papel estratégico, pois atrela a educação ao mercado tirando dela os mais adaptados às suas novas exigências empresariais; torna a escola adequada aos seus princípios doutrinadores por meio da transmissão de seus valores; sob a orientação do Banco Mundial. Eles sugerem a privatização das escolas o quanto antes e ainda exigem a redução imediata do financiamento público das escolas por parte dos governos, esses obedecem como "cordeirinhos" esse receituário monstruoso contra a maior parte da população.

O discurso neoliberal afirma que as escolas, bem como toda a educação formal, devem passar a fazer parte dos interesses empresariais, ou seja, são objetos de troca no mercado. Afirmam seus teóricos que a educação teria maior credibilidade e legitimam as reformas educacionais. Reformas que com certeza prejudicam o desempenho da maioria. Tanto de alunos quanto de professores e ainda da própria escola e/ou universidade.

Para os neoliberais de plantão a educação deve ser voltada ao mercado, ou seja, com muita adaptabilidade e ajuste ao mercado, produtividade, competitividade, rentabilidade e mensurabilidade (GENTILI, 2002, p. 157), pois assim satisfaria melhor

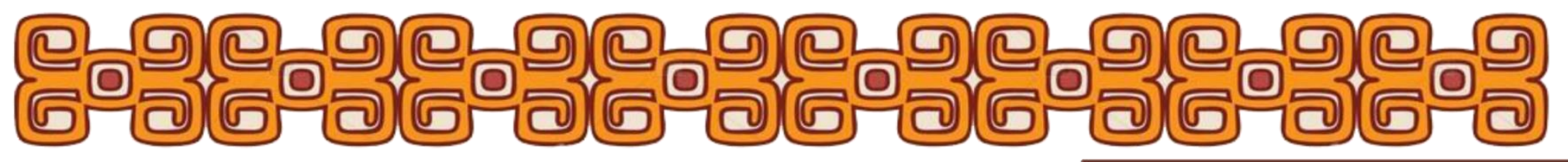




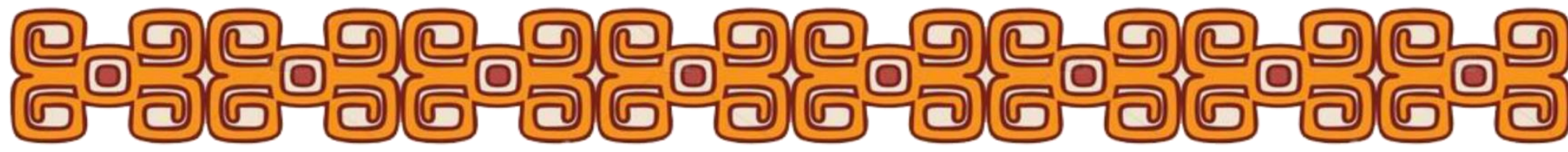

Para a elite que mantém a política e a economia seus defensores neoliberais a privatização da escola pública tem a ver com a evolução individual e aquele que não tem como pagar teve azar biológico ao nascer.

Assim a criança pobre é atirada para os muros da desigualdade social e intelectual (CHOMSKY, 1999, p. 189-90).

Desta forma, o Estado vai tirando sua responsabilidade de manter a escola financeiramente e reduz sua participação na formação das futuras gerações transferindo para os pais e comunidade a responsabilidade que era sua e, desta forma, deixa por conta somente dos interesses das empresas essa função. E o Estado ainda procura contribuir com algumas facilidades para os empresários da educação (GENTILI, s/data, p. 324-6). Como por exemplo, abrindo as escolas para a entrada de capital das empresas. Ou ainda, proporcionando participações dos alunos em atividades produtivas e reprodutivas dentro das fábricas. Ou aplicando projetos com verba privada nas escolas públicas. Outra forma é entregando prêmios aos professores mais produtivos, ou seja, aqueles que seguiram o receituário do sistema ora em andamento e ainda criando cursos profissionalizantes voltados para especialmente atender as demandas das empresas.

Eles não entendem a escola e a educação de modo geral como um bem básico. Na verdade, querem é o mais rápido possível tirar esse direito da constituição, para privilegiar aos donos de escola que receberão os "novos" clientes, ou seja, pobres oriundos das escolas públicas, pois com o fim da escola pública que se aproxima encaminharão seus filhos para as escolas privadas. Mesmo que sejam escolas sem nome lá de um bairro distante, mas serão as escolas que estarão à disposição para esses "novos clientes" que são na verdade os nossos "antigos" alunos.

E por esse feito magnânimo os empresários da educação ainda se autointitularam com a grandeza do título atualmente pomposo e bonito de ser divulgado em suas propagandas de que são "os responsáveis sociais", a dita responsabilidade social tão em voga atualmente pelas propagandas das grandes empresas da educação.

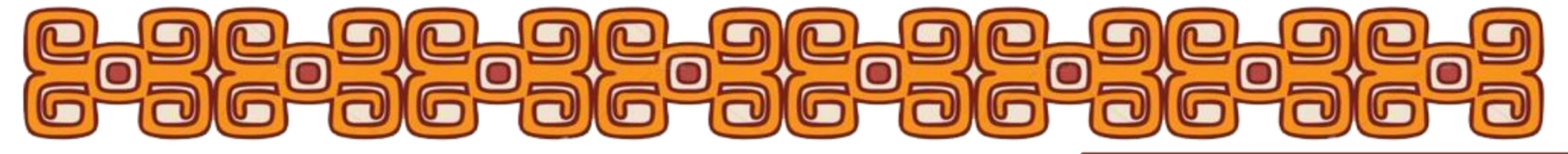




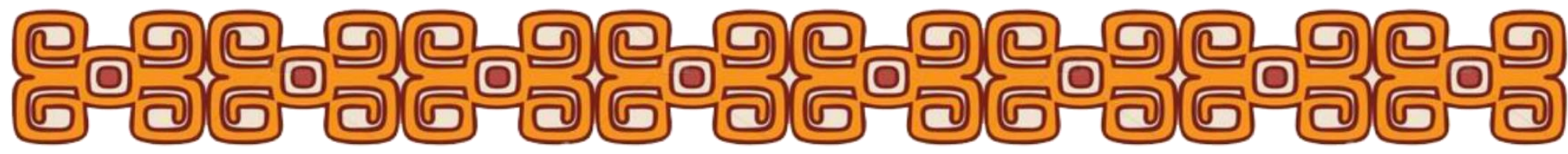

Eles receberão estes alunos, claro, mediante as bolsas-educação financiadas pelo governo, uma transferência do dinheiro público diretamente para os cofres, já lotados há muito tempo, dos donos dos meios de produção, ou seja, dessas escolas particulares que substituirão as públicas em todas as regiões.

O dinheiro que antes mantinha todas as escolas públicas agora é "sem sentido de existência" dentro dos novos padrões neoliberais assim pode ser usado para investimentos nos grandes negócios neoliberais. Ora para que dinheiro investido na escola, ou hospitais públicos, que nós neoliberais queremos mesmo fechar ou garantir o seu desequilíbrio orçamentário futuro.

Caso se perpetue o modelo das escolas privadas, como é o desejo dos neoliberais, os cidadãos serão transformados em consumidores. E consumidores não tomam e nem partilham as decisões. Principalmente as decisões que lhes dizem mais respeito.

É preciso exigir que nas escolas sejam realizadas eleições para diretor, por exemplo, para garantir um pouco de transparência às ações ali realizadas. Numa gestão democrática o consumidor é transformado em cidadão, ao contrário do receituário proposto pelos esforços da teoria neoliberal.

Nas escolas deve-se ainda, para fugir dos ditames impostos pelo sistema atual, criar condições para que surja dentro dela mesma uma organização tal que garanta a colaboração e participação de todos. Assim, todos se sentirão importantes dentro do processo de educação desenvolvido pela escola.

A escola desconectada das intenções dos mandatários do sistema deve priorizar a igualdade entre todos. Assim, favorecerá os mais necessitados e que estão excluídos da participação atualmente na sociedade.

Deve ainda incentivar a democracia dentro e fora dos muros da escola. Desta forma colaborará para a sociedade formando cidadãos crentes na possibilidade de transformação por meio da democracia real, ou seja, a participativa de todos e sempre.

Deve também buscar a integração dos cidadãos e suas mais diversas formas de ver, pensar e agir no mundo. Integrando valores múltiplos e não somente os valores

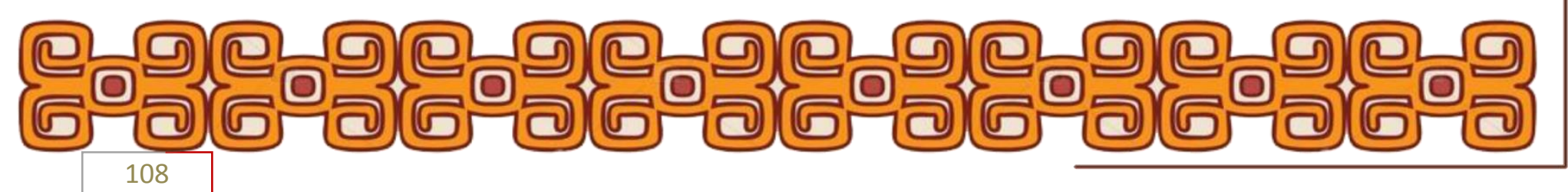




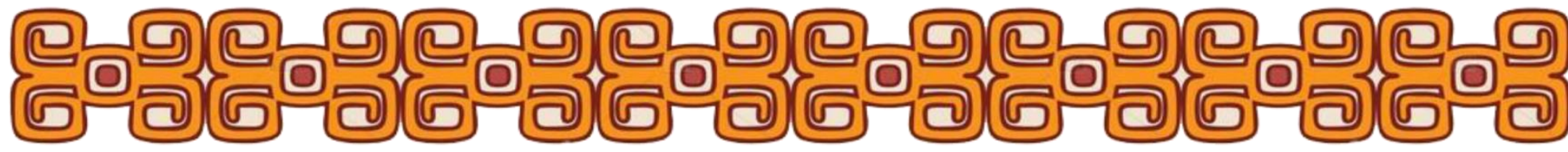

do receituário neoliberal, indicados pelos mais poderosos por meio do Banco Mundial e Fundo Monetário Internacional.

É mais que urgente então transgredir as regras impostas pelos ditadores atuais e rever a importância da escola, principalmente as públicas para a vida social do país. Não aceitando mais que os educandos sejam tratados como coisa ou consumidores da mercadoria educação.

É preciso ainda reivindicar a autonomia escolar prevista na LDB - Lei de Diretrizes e Bases da Educação Nacional em vigência desde 1996. A autonomia escolar muito propagada nessa lei ainda é impossibilitada de ser cumprida graças à burocracia do sistema.

Exigir a transparência em todas as prestações de contas nas escolas e que elas sejam feitas de forma pública e aberta para todos os partícipes das escolas. Entre outras medidas democratizantes, como a participação de comunidade, pais, alunos, funcionários, direção e professores nas tomadas de decisões nas quais têm estreita relação. Que não sejam mais aceitas medidas tomadas nos "escurinhos" ou escondidas nas escolas e/ou ainda a portas fechadas.

A educação precisa deixar de ter dois setores. Um que seja destinado à educação dos ricos, que é voltada para a ciência e a tecnologia que estimula e incentiva a criatividade e a autonomia, e, ainda, para controlarem a vida e a educação do outro setor, ou seja, o dos pobres. Treinado para obedecer, ser dócil, passivo e, de preferência, ignorante, no sentido de desconhecer seus direitos, aceitador da manipulação externa a ele mesmo.

Não podemos mais aceitar isso. Precisamos de escolas livres e que ajudem os educandos a pensarem por si mesmos, mesmo que isso seja um perigo para o sistema (CHOMSKY, 1996, p. 40-1). Talvez seja ótimo ser um perigo para esse sistema. Pensar não pode ser mais perigoso ou tratado como sendo. Ter liberdade de pensar e agir nas escolas é muito importante para o desenvolvimento da cidadania ativa.

É preciso enfatizar a alfabetização da crítica que convida grupos representantes das mais diversas correntes do pensamento contrário ao sistema para apresentar-se na interação sala de aula e diálogo sua realidade, seus valores e

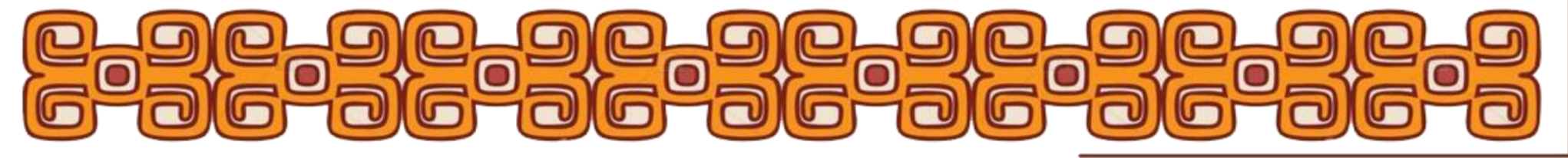




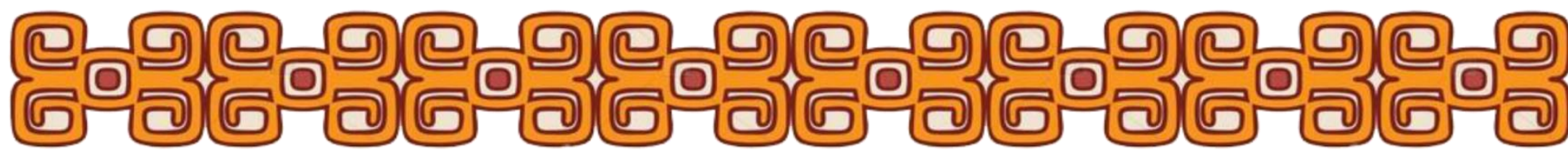

Mais imposturas as câmeras internas para vigiar e punir diretamente os alunos e indiretamente os professores. Logicamente também transferindo fontes e subsídios públicos para as empresas privadas com essas operações.

Problemas com os quais as nossas escolas e seus respectivos usuários têm que enfrentar hoje e esse enfrentamento deve ser feito com muita garra e determinação, pois sem esses sentimentos seremos omissos e passaremos num futuro bem próximo a fazer parte de uma instituição acabada, e não mais falida como é ainda hoje! Então acreditamos que ainda há tempo para a mudança e outro mundo é possível.

\section{OUTRO MUNDO É POSSÍVEL?}

Os vencidos de agora serão os vencedores de amanhã. E o hoje nascerá do jamais.

Brecht

Diferente completamente do que dizem os neoliberais é possível sim outro mundo, sem toda essa desigualdade social e injustiça econômica. Existem saídas diferentes para as mais diversas situações encontradas em nossa sociedade global que não a imposição de um modelo neoliberal e todo seu bestial ideário.

Um dos maiores objetivos daqueles que querem outro mundo é começar a mostrar aonde puderem que a resistência existe e que há lutas para mudar o mundo. Não apenas mostrarmos as vítimas. Somos sim vítimas, mas podemos lutar para mudar e não devemos nos desanimar nunca!

Em toda a América Latina, como também em outros locais do mundo explorado (África e Ásia) e também na Europa empobrecida, hoje há sinais de movimentos em luta pela transformação da sociedade global para que ela seja mais justa e igualitária.

Não podemos esquecer-nos dos diversos movimentos sociais que incessantemente brigam por outro mundo, Zappatismo no México, Tupac Amaru no Peru, MST no Brasil, Intifada na Palestina, IRA na Irlanda, ETA na Espanha, MSTC no

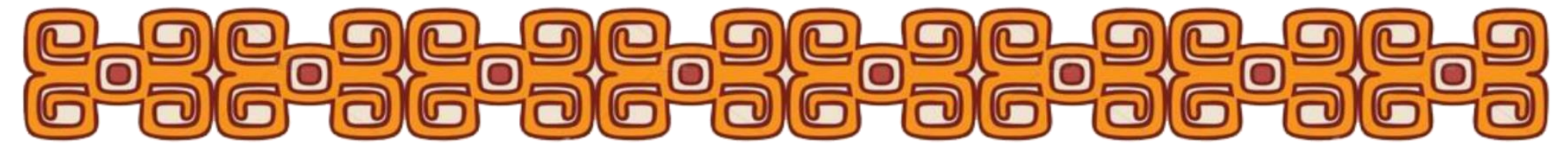




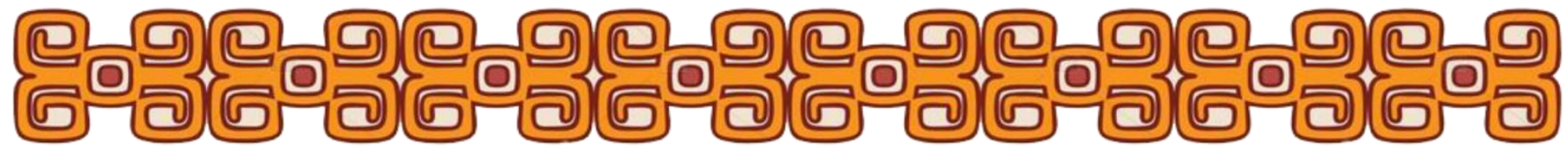

A composição de um movimento mundial pelos direitos humanos

econômicos se faz necessária, tal composição seria formada pelas coligações por parte das vítimas do sistema econômico e dos movimentos sociais em todos os níveis: local, municipal, estadual, federal, continental e mundial (CHOMSKY e DIETERICH, 1999, p. 261). Já Immanuel Wallerstein chama a atenção para a história; descreve que ela nada garante, mas que devemos lutar caso queiramos mudar e ter progresso. $\mathrm{E}$ somente com muita inteligência e vontade coletiva é que conseguiremos (WALLERSTEIN, 2002, p. 250).

Somente uma ação coletiva com base popular, com um amplo estrato da população participando e comprometida com a eliminação das instituições autoritárias, estatais ou privada, é que mudaremos o mundo, é preciso que se faça algo se quisermos escapar da barbárie imposta pelos neoliberais (CHOMSKY, 2007, p. 54). Assim caminharemos para um mundo com mais dignidade e justiça para todos.

A existência de uma luta de todos em tempo integral facilitaria os esforços sociais. Não somente na hora da manifestação de rua, é preciso que seja atuante sempre. É bom que a sociedade seja democrática e que esteja em funcionamento a democracia, com a presença de associações populares, de sindicatos e de grupos políticos tratando dos assuntos que lhes dizem respeito o tempo todo (CHOMSKY, 2006, p. 180).

Lembrando Brecht há homens/mulheres que lutam a vida inteira e esses sim são imprescindíveis para a humanidade e para as mudanças que tanto buscamos e desejamos. Em nome desse ideal conclamamos a todos:

LUTEM sempre, enquanto vivos, isso, sim, fará toda a diferença...!

\section{REFERÊNCIAS}

AZEVEDO, Janete M. Lins de. A educação como política pública. Campinas: Autores Associados, 2004.

BARBER, Benjamin R. O império do medo: guerra, terrorismo e democracia. Rio de Janeiro: Record, 2005.

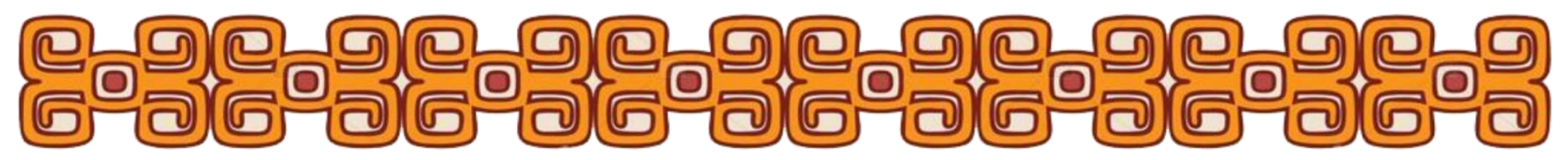




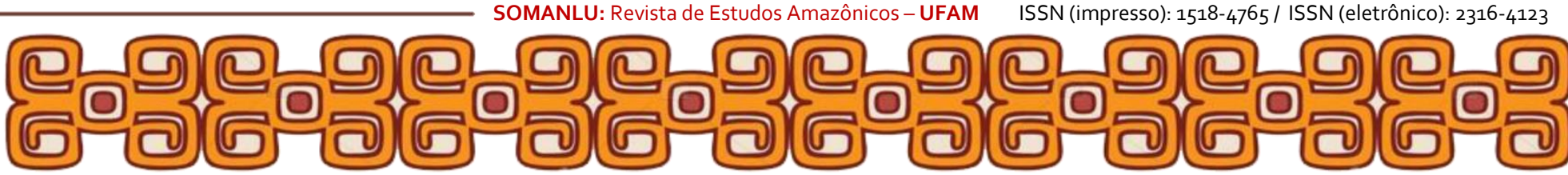

BARBOSA, Alexandre de Freitas. O mundo globalizado: política, sociedade e economia. São Paulo: Contexto, 2001.

BIANCHETTI, Roberto G. Modelo neoliberal e políticas educacionais. São Paulo: Cortez, 2005.

BIONDI, Aloysio. O Brasil privatizado: um balanço do desmonte do Estado. São Paulo: Fundação Perseu Abramo, 1999.

BORON, Atílio A. Estado, capitalismo e democracia na América Latina. São Paulo: Paz e Terra, 1994.

BORON, Atílio A. Nova hegemonia mundial: alternativas de mudanças sociais. Buenos Aires: Consejo Latinoamericano de Ciencias Sociales, 2004.

CARVALHO, Bernardo de Andrade. A globalização em xeque: incertezas para o século XXI. São Paulo: Atual, 2000.

CHOMSKY, Noam. Sistemas de poder. Conversas sobre as revoltas democráticas globais e os novos desafios ao império americano. Rio de Janeiro: Apicuri, 2013.

CHOMSKY, Noam e DIETERICH, Heinz. A sociedade global: educação, mercado e democracia. Blumenau: FURB - Universidade Regional de Blumenau, 1999.

CHOMSKY, Noam. Ambições imperiais. Rio de Janeiro: Ediouro, 2006.

CHOMSKY, Noam. Neoliberalismo e ordem global: crítica do lucro. Lisboa: Notícias, 2000.

CHOMSKY, Noam. O governo do futuro. Rio de Janeiro: Record, 2007.

CHOMSKY, Noam. O império americano: hegemonia ou sobrevivência. Rio de Janeiro: Elsevier, 2004.

CHOMSKY, Noam. O lucro ou as pessoas? Neoliberalismo e ordem global. Rio de Janeiro: Bertrand Brasil, 2002.

CHOMSKY, Noam; ASSMANN, Hugo e SANTOS, Theotonio dos. A trilateral nova fase do capitalismo. Petrópolis: Vozes, 1979.

CHOMSKY, Noam; ROY, Arundhati e AMIN, Samir. A ofensiva do império e os dilemas da humanidade. São Paulo: Movimento de Consulta Popular, cartilha no 13 , 2003.

CREAGH, Ronald. O dia em que o mundo mudou. São Paulo: Imaginário, 2001.

FIORI, José Luís. Os moedeiros falsos. Petrópolis: Vozes, 1998.

FRIEDMAN, Milton. Capitalismo e liberdade. São Paulo: Nova Cultural, 1988.

GENTILI, Pablo e SILVA, Tomaz Tadeu da (orgs.). Neoliberalismo, qualidade total e educação: visões críticas. Petrópolis: Vozes, 2002.

GENTILI, Pablo (org.). Globalização excludente: desigualdade, exclusão e democracia na nova ordem mundial. Petrópolis: Vozes, 2002.

GONÇALVES, Reinaldo e POMAR, Valter. O Brasil endividado: como nossa dívida externa aumentou mais de 100 bilhões nos anos 9o. São Paulo: Fundação Perseu Abramo, 2001.

GRISOLIO, Lilian Marta e JUSTAMAND, Michel. Políticas educacionais: o projeto neoliberal em debate. Embu das Artes: Alexa Cultural, 2007.

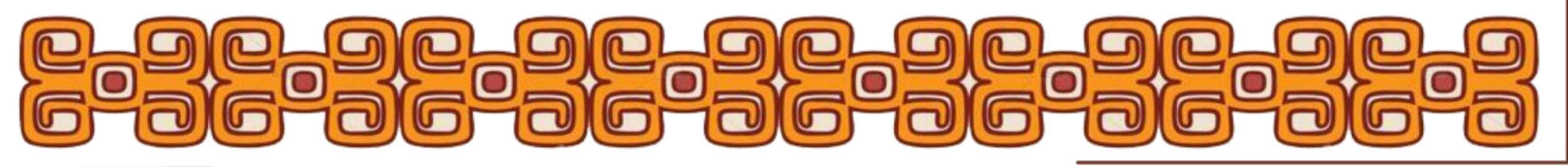




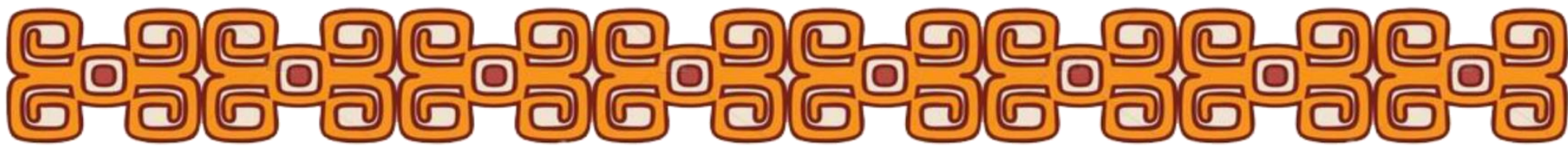

HAYEK, Friedrich A. O caminho da servidão. São Paulo: Globo, 1977.

HOBSBAWM, Eric. Globalização, democracia e terrorismo. São Paulo: Cia. das Letras, 2007.

IANNI, Octávio. A era do globalismo. Rio de Janeiro: Civilização Brasileira, 1999.

JAKOBSEN, Kjeld; MARTINS, Renato e DOMBROWSKI, Osmir. Mapa do trabalho informal: perfil socioeconômico dos trabalhadores informais na cidade de São Paulo. São Paulo: Fundação Perseu Abramo, 2001.

JUSTAMAND, Michel. A águia e suas garras: EUA, Chomsky e Nicarágua. Ariadna Tucma Revista LatinoAmericana, n. 9, mar 2014/fev 2015, vol. II.

JUSTAMAND, Michel. Neoliberalismo: a máscara atual do capital. Rio de Janeiro: Achiamé, 2010.

KURZ, Robert. Os últimos combates. Petrópolis: Vozes, 1997.

LINHARES, Célia Frazão e GARCIA, Regina Leite (orgs.). Dilemas de um final de século: o que pensam os intelectuais. São Paulo: Cortez, 1996.

MATTOSO, Jorge. O Brasil desempregado: como foram destruídos mais de 3 milhões de empregos nos anos 9o. São Paulo: Fundação Perseu Abramo, 1999.

MCLAREN, Peter e FARAHMANDPUR, Ramin. Pedagogia revolucionária na globalização. Rio de Janeiro: DP\&A, 2002.

MOORE, Michael. Cara, cadê meu país? São Paulo: Francis, 2004.

PEDEX, Programa Educativo Dívida Externa. O neoliberalismo: ou o mecanismo para fabricar mais pobres entre os pobres. São Paulo: CADERNOS Dívida Externa no 3 , 1993.

POCHMANN, Márcio. O país dos desiguais. São Paulo: Le monde diplomatique, Brasil. Ano 1, no 3 , out 2007.

RIFKIN, Jeremy. O fim dos empregos: o declínio inevitável dos níveis dos empregos e a redução da força global de trabalho. São Paulo: Makron Books do Brasil, 1995.

ROMÃO, José Eustáquio. Dialética da diferença: o projeto da escola cidadã frente ao projeto pedagógico neoliberal. São Paulo: Cortez, 2000.

RYOKI, André e PRTELLADO, Pablo. Estamos vencendo! Resistência global no Brasil. São Paulo: Conrad, 2004.

SADER, Emir e GENTILI, Pablo (orgs.). Pós-neoliberalismo: as políticas sociais e o estado democrático. São Paulo: Paz e Terra, 2003.

SAID, Edward W. Cultura e política. São Paulo: Boitempo, 2003.

SAID, Edward. Orientalismo. São Paulo: Cia. das Letras, 1990.

SILVA, Luiz Heron da (org.). A escola cidadã no contexto da globalização. Petrópolis: Vozes, s/data.

WALLERSTEIN, Immanuel. O universalismo europeu: a retórica do poder. São Paulo: Boitempo, 2007.

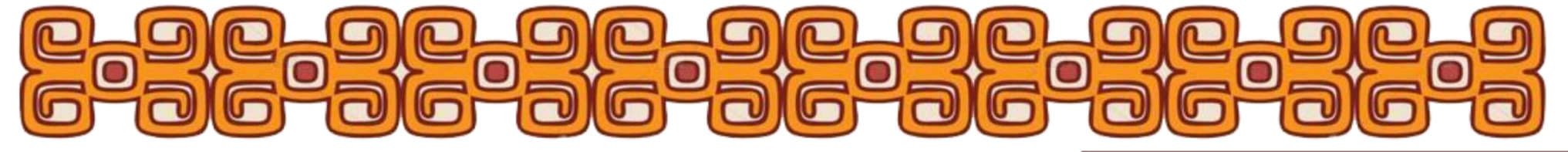

